\title{
Bumpy moments considered as critical incidents in dialogue. Professional Identity of technical VET-teachers
}

\author{
Los momentos difíciles como incidentes críticos en diálogo. Identidad \\ profesional de los profesores de FP técnica
}

Kara Vloet

Fontys University of Applied Sciences

Ellen Klatter

Rotterdam University of Applied Sciences

\author{
Sandra Janssen \\ Fontys University of Applied Sciences
}

Giel Kessels

Car Academy, Summa College VET, Eindhoven

\begin{abstract}
Technology students need strong vocational education that supports both cognitive and career development in order to be adequately prepared for highly qualified jobs. The professional identity and underlying I-positions of teachers largely determine whether the quality of teaching meets these requirements. In an in-depth study we explored the professional identity of teachers working in technical VET. Bumpy moments as indicated by eleven teachers were discussed and analysed both qualitatively and quantitatively. The results show that teachers largely identified bumpy moments relating to their pedagogical content knowledge. Most teachers in the technical domain predominantly reflected an I-position as being a professional expert. We conclude that the dominant focus on pedagogical content knowledge legitimises professionalisation in favour of cognitive development and the career development of youngsters. By incorporating dialogue derived from the flower model can help teachers to better understand their professional identity, determining the quality of vocational education.
\end{abstract}

Keywords: Vocational Education; Pedagogy; Professional Identity; Critical Incidents of Dialogical Self

\section{Resumen}

Los estudiantes de tecnología necesitan una sólida formación profesional que apoye tanto su desarrollo cognitivo como profesional, a fin de estar adecuadamente preparados para trabajos altamente cualificados. La identidad profesional de los profesores y sus I-positions subyacentes determinan en gran medida si la calidad de la enseñanza cumple los requisitos. En un estudio en profundidad exploramos la identidad profesional de los profesores que trabajan en la formación profesional técnica. Se discutieron y analizaron, tanto cualitativa como cuantitativamente, los momentos difíciles señalados por once profesores. Los resultados muestran que los profesores identificaron en gran medida los momentos de dificultad en relación con sus conocimientos pedagógicos. La mayoría de los docentes de tecnología reflejaron predominantemente una I-position como profesionales expertos. Concluimos que el enfoque dominante en base al conocimiento pedagógico legitima la profesionalización en favor del desarrollo cognitivo y el desarrollo de la carrera de los jóvenes. La incorporación del diálogo derivado del denominado "Flower model" puede ayudar a los profesores a comprender mejor su identidad profesional, determinando la calidad de la formación profesional.

Palabras clave: Educación vocacional; Pedagogía; Identidad profesional; Momentos difíciles del yo dialógico 


\section{INTRODUCTION}

Highly qualified employees are increasingly in demand within the technical industry all over the world. In order to keep up to date with technical developments across the industry an alternative method of training and education within the technology curriculum is required (SBB, 2019). For example, due to digitalisation and the resulting available data, an engineer's daily working activities are constantly changing. Technical operations will shift more from the physical to the digital domain. Based on the principles of the safety domain training not only demands the development of mental resilience, the development of a professional attitude or continuous training of professional skills, it also needs continuous development in the field of Technology (SBB). Social skills and assessment skills are increasingly important in combination with upto-date knowledge about technical systems (Techniekpact, 2020; Fouarge et al., 2017; Virtanen \& Tynjala, 2019) to be able to respond adequately to technological developments. The professionalisation of current teachers and the increase of teachers with an educational master's degree for secondary education is therefore an undiminished goal (Techniekpact, 2020). As such, requirements are continuously changing and irrevocably involves the role of technical teachers and teacher trainers in Vocational Education training in Technology (VET).

This study was conducted within the context of a technical Teachers Training Institute (TTI). As the primary goal of teaching Technology is to encourage students' learning processes with regard to technological concepts, teaching VET requires substantive domain knowledge and specific knowledge of learning processes of the target group. Lee Shulman (1986) coined this combination as Pedagogical Content Knowledge (PCK); 'that special amalgam of content and pedagogy that is uniquely the province of teachers, their own special form of professional understanding' (p. 8). Teachers' beliefs about how to meet the educational goals set, influence the choices they make within their teaching repertoire. Underlying issues refer to the professional identity of teachers. What do teachers conceive to be important in their teaching assignment and to what extent are they confident and motivated in shaping these orientations with regard to their students? However, little is known about the professional identity of technical teachers and how their professional identity becomes resonated in their educational practices. This study's aim is to provide more insight in this rather unexplored field. 


\section{THEORETICAL FRAMEWORK}

\section{Flower model in VET}

Teachers' professional identity forms the heart of education, as they are the ones who prepare students for future life and careers. In order to meet requirements for powerful vocational education training within technology, a so-called flower model was introduced by the Association of Universities of Applied Sciences in The Netherlands (2012) as an extension of the model of pedagogical content knowledge (Shulman, 1986). Although Shulman's model is valuable for understanding relationships between educational strategies and learning processes, the flower model provides a wider framework as it also includes the target group at

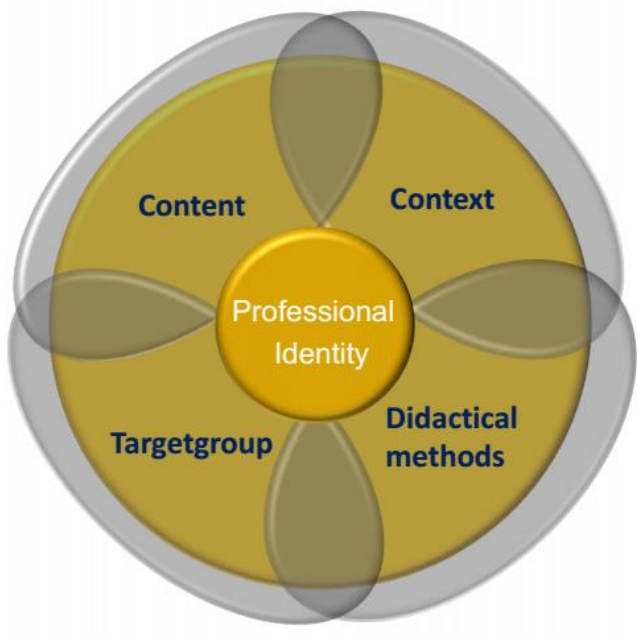

Figure 1. Flower model (Association of Universities of Applied Sciences, 2012) hand and the context of the professional practice for which students are educated (figure 1).

This flower model includes five educational areas that are often studied separately but in educational practice are always intertwined (De Putter-Smits, 2012; Schneider \& Plasman, 2011; Stuckey, Hofstein, Mamlok-Naaman \& Eilks, 2013). The areas are therefore depicted as four overlapping petals surrounding the heart, which represents the teacher's professional identity.

Teachers are assumed to possess an elaborated mental framework regarding the petal of content knowledge, also referred to as subject matter knowledge (SMK) (Teune \& Janssen, 2015). SMK is about personal insight into the interrelationships between important (sub)concepts, procedures, theories and principles of various subjects. Teachers will need to know how this SMK grows through teaching and learning strategies. Knowledge about learning strategies is needed to guide students in adapting and assimilating their mental models on the subject (Van Driel \& Verloop, 2004). In the flower model, the concept of PCK can be visualised as an axis on the content and didactic aspects, in which the professional identity of the instructor, as the focal point, is strongly determinative. 
Working in vocational education also requires thorough knowledge of the target group, in all its diversity and awareness of the students' motivation and mentality, in addition to knowledge of the technical context as the professional field for which education is being provided. Contextual knowledge is particularly relevant as technical VET teachers need to be aware of the rapidly changing field of work. The heart of the flower represents teachers' professional identity (TPI), conceptualised as the teacher's beliefs about education and how a teacher perceives himself as a professional, his task-concept and self-image (Vloet, 2015). This relates to his choices in education with respect to the petals.

For teachers it is the art to view the world of learning through the eyes of the students (Hattie, 2012). When a strategy does not work for an individual student, teachers must be able to adopt another strategy better fitting the needs and goals in that specific moment. Teachers should have as many alternative learning strategies as possible at hand and be able to use them consciously and responsibly. However, several studies show that teachers' working repertoire in vocational education remains limited and does not offer enough variety to provide custom work (De Bruijn \& Van Kleef, 2006; De Bruijn \& Leeman; 2011). Although the arsenal of didactic forms of work is nearly inexhaustible, teachers generally use a limited set of instructional strategies (Klatter \& Vloet, 2013). As such, the alignment of pedagogical and didactical methods to the needs of the student, does not yet seem optimally realised in educational contexts (Glaudé, Van den Berg, Ter Beek \& de Bruijn, 2011).

Teachers therefore need to be well acquainted with their students, not only the competences they are supposed to develop, but also what interests them, what kind of learning objectives they set for themselves, and what kind of work would suit them. To thoroughly understand these issues and to read the underlying learning processes more explicitly, teachers should personally relate to their class and feel involved with each student and his or her personal goals (Van Driel \& Verloop, 2004). This combination represents a second axis called 'career development' (Klatter, 2015; Kuijpers, 2015). In this manner, teachers increasingly (need to) become a students' coach, not only with regard to their cognitive learning processes, but also with regard to their career development and preparing them for the future professional fields (Grootendorst, 2019).

The question is whether technical VET teachers have the skills to tailor their teaching to the variety of needs of their students. Not only in terms of instructional strategies promoting students' learning processes, but also in adapting the subject matter to future professional fields, and guiding their career choices, within their classes. In doing so, all four petals of the flower model must be 
involved. One presumes this only occurs when the teacher is aware of the importance of each of the four concepts, and understands their mutual relationship (Klatter \& Stroetinga, 2011). It also presupposes the teacher considering it as his task to work on fully-fledged professional education, in which both the cognitive and the career development deserve attention.

However, several earlier exploratory small-scale studies showed that teachers and educators in the technical field of education mainly act as content experts (Janssen, 2012; Klatter \& Stroetinga, 2011; Klatter \& Vloet, 2013). They predominantly focus on the content of the subject matter than on the learning processes of their students and their learning attitude. As a result, the educational design of technical teachers is quite traditional, with classroom lectures, small-scale group work and content-related questions appearing to be dominant. Moreover, learning objectives are not always formulated or made explicit to the students during lessons. They only marginally reflect on their teaching activities in relation to their students' learning processes and the goals set by themselves. This predominant focus on information transfer does not guarantee a thorough understanding of the subject matter or the ability to adapt knowledge to new, complex areas, as is assumed for technicians in (future) unknown positions (Teune \& Janssen, 2015). The question is whether teachers are willing and able to deal with goals which are aimed at the career development of their students, and if so, to what extent they act accordingly in their teaching practice. The task concept and self-image of the teachers are then at stake, as part of their professional identity, the heart of the flower model.

\section{Teachers' Professional Identity}

The professional identity of teachers can be traced by relatively simple questions such as 'who am I as a teacher' and 'what kind of teacher do I want to be', but the answers are usually more complex. In a review-study on teachers' professional identity (TPI) (Beijaard, Meijers \& Verloop, 2004) four essential features of teachers' professional identity were derived. TPI as:

a. an ongoing process of interpretation and re-interpretation of experiences (e.g. Kerby, 1991),

b. the implication of both person and context (e.g. Feiman-Nemser \& Floden, 1986),

c. the inclusion of sub-identities that more or less harmonise (e.g., Volkmann \& Anderson, 1998) and, 
d. agency as being an important element of TPI, meaning that teachers have to be active in the process of professional development (e.g. Coldron \& Smith, 1999).

As such, a professional identity is not fixed, but evolves over time (Pillen, 2013). This evolvement depends on professionalisation in the field and the increasing knowledge of educational strategies as a result of growing experience (Park \& Oliver, 2008). Douwe Beijaard et al. (2004) also suggested that research should focus more on identity in relation to the self of the teachers, on the role of context in the development of TPI, and on both the emotional and cognitive dimensions. Therefore, a sociological narrative research tradition was advocated focusing on teachers' experiences, as previously promoted by John Dewey $(1922 / 2002)$ and more recently by Harry Kunneman (2010). By means of narrative inquiry, the continuity and richness of teachers' experiences in their professional practice and lives can be understood (Clandinin \& Connelly, 2000).

From a narrative perspective, Geert Kelchtermans (1994; 2009) showed how teachers develop a personal interpretative framework, composed of their professional self-understanding and their subjective educational theory. Teachers' subjective educational theory is considered as a set of (subjective) cognitions or mental representations, operating as a lens through which they view their work, providing meaning, and to act upon it. Their professional selfunderstanding, here referred to as professional identity, is evolving over time and consists of five interrelated parts (Kelchtermans, 1994, pp. 89-90; 2009): self-image, self-esteem, job-motivation, task-perception and futureperspective. According to Kelchtermans, teachers' professional selfunderstanding and their subjective educational theory are two interwoven domains within the personal interpretative framework that teachers develop to interpret and give meaning to professional situations; they are intertwined in the teachers' educational practice.

Teachers' professional identity is also conceived as multi-voiced (Beijaard, et al., 2004). In the Dialogical Self Theory (DST) identity, referred to as the self, consists of different I-positions that are in dialogue (Hermans \& Kempen, 1993; Hermans \& Hermans-Konopka, 2011). Based on this theory, Sanne Akkerman and Paulien Meijer (2011) define a teachers' identity as 'an on-going process of negotiating and inter-relating multiple I-positions in such a way that a more or less coherent and consistent sense of self is maintained throughout various participations and self-investments in one's (working) life.' (p. 315) The position I as a teacher is continuously used in dialogue (negotiates, agrees, feels unhappy, or even fights) with other I-positions that are not only inside the teachers' self but also outside the self (for example my subject, my students, my col- 
leagues are then conceived as part of the self) (Kunneman, 2010; Vloet, Jacobs \& Veugelers, 2013). Some Ipositions can be found more in the centre of the self, while others might be more peripheral. Teachers of subject matter might see themselves for example mainly as experts in their field of study, but they are also pedagogues to their students in a didactical way and they can have a supervisory position as a students' coach in students' career development processes. Hence, from a DST perspective the four interrelated petals of the flower model can be perceived as different internal Ipositions within the teacher's pro-

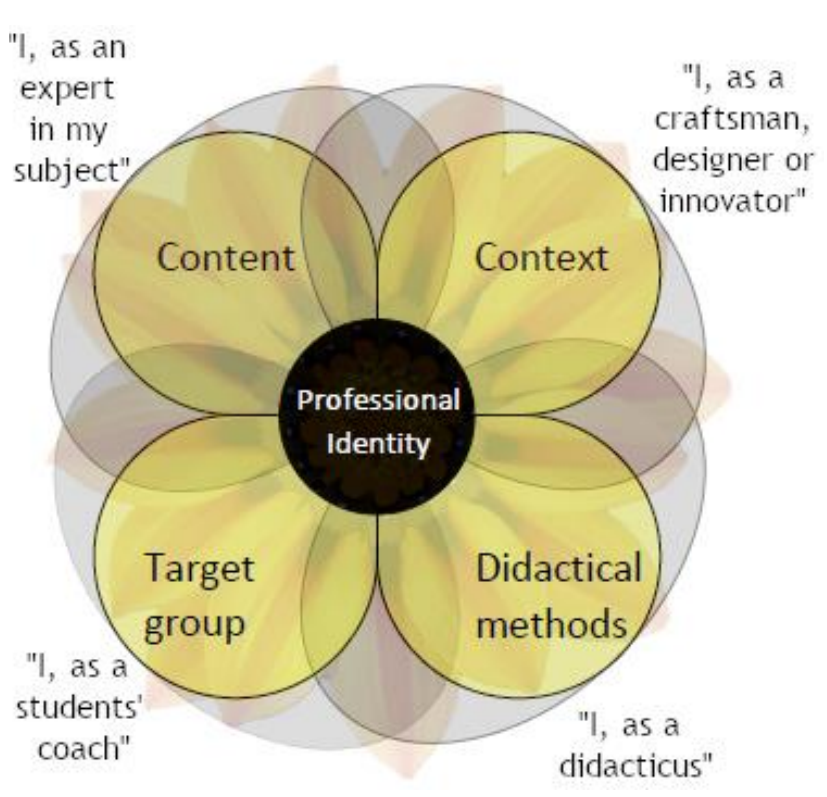

Figure 2. Flower model related to different Ipositions within the dialogical self fessional identity, whereas 'my content', 'my target group', 'my didactical methods' and 'my context' can be referred to as external I-positions (figure 2).

Kara Vloet (2015) shows how professional identity, based on Kelchtermans' notions, can be conceptualised as six interrelated components. In Figure 3, the box on the right hand side shows three components of TPI on a cognitive level:

1. job-motivation: teacher's reason to choose, remain committed or leave the job,

2. task-concept: teacher's definition of the job or his daily tasks, and

3. self-image: the way a teacher describes himself.

Additionally, there are three components on an emotional level:

4. motives: teacher's drives to do his daily work,

5. task-experience: evaluation of the task, and

6. self-experience: evaluation of the teacher as a professional, as defined by self or others.

In this model the broad concept 'self-experience' replaces the more specific concept of 'self-esteem' as introduced by Kelchtermans (2009). Self-image consists of several sub-identities that harmonise to a greater or lesser extent and are perceived as a dialogical self of I-positions as distinguished in the work 
of Herbert Hermans and colleagues (Hermans \& Kempen 1993; Hermans \& Hermans-Konopka, 2011).

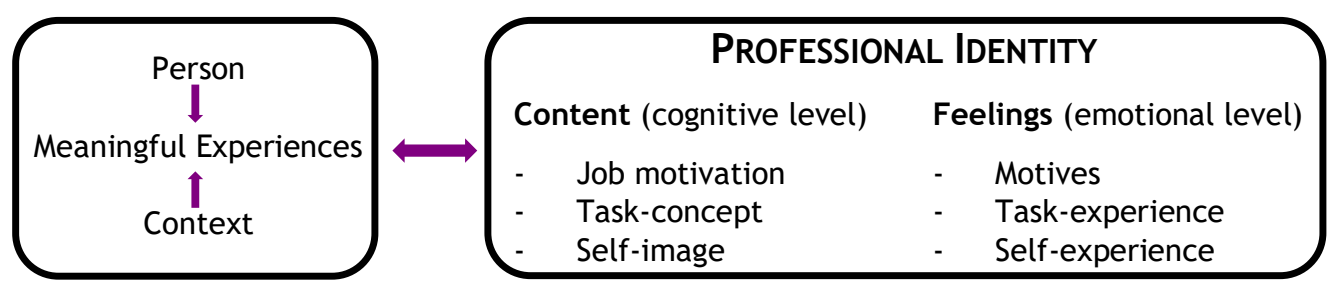

Figure 3. Model of Teachers' Professional Identity as interrelated components (Vloet, 2015)

The double-sided arrow in Figure 3 expresses interaction between professional identity and meaningful experiences, in a dialogical manner. The left hand side of the model in Figure 3, illustrates how meaningful experiences in the professional or personal context of a teacher can influence the professional identity on a cognitive and/or emotional level. On a cognitive level, job motivation refers to teachers' motives or drives over time to become, to remain a teacher or to leave the job. The teacher's task concept and self-image refer to his identity related to the performance of his professional role. Influences of meaningful experiences on the emotional level can impart joy or cause anxiety or uncertainty concerning his task.

In line with Beijaard et al. (2004) Vloet's model assumes that professional identity is a fluid concept; teachers' opinions and views on their teaching task and being a teacher can determine their reflections on what 'meaningful experiences' are to be found in their classroom, and vice versa. Referring to educational practice as a starting point our question is; what do teachers perceive as meaningful experiences in their lessons? Deep reflection on meaningful educational experiences is required to reveal teachers' professional identity and the impact on their teaching practices (Korthagen \& Vasalos, 2005). In line with Beijaard et al. (2004), in this study we pay attention to the concepts of self and identity and focus on the emotional level of the professional identity.

\section{Bumpy moments considered as critical incidents in class}

Teachers' professional identity can be elicited by deep reflective dialogue on meaningful experiences, for example, in problematic class-situations. For this purpose, Molly Romano's (2006) definition of bumpy moments is useful: “A teaching incident that requires the teacher to engage in reflection to make an immediate decision how to respond to a particular problem in practice can be 
defined as a bumpy moment" (p. 974). In these unexpected situations, teachers are required to respond in a split second, acting on their intuition and underlying values. As such, teachers' pedagogical reactions often rely on their implicit beliefs (Romano, 2006).

Bumpy moments were recognised as situations that, from the teachers' perspective, legitimately permits a different or alternative teaching strategy (Van Kan, Zitter, Brouwer \& Van Wijk, 2014). Such moments are valuable as concepts to precisely elicit those situations that teachers experience as meaningful. Deep reflection can evoke a subjective understanding of the participant's experiences with the specific phenomenon. What do teachers experience as critical in the moment, and what kind of identity is reflected by teachers' reactions in this actual situation? From what point of view were they called upon? How do they show themselves, what pedagogical orientation is expressed in that specific situation? And what kind of intentional goals did they strive for? The appeal they feel colours their underlying beliefs and allows them to express their professional identity on a cognitive and emotional level (Van Manen, 2007; Pols, 2011). Answers to these questions continue to be influenced on a social and cultural level. (Dowling, 2007; Van Manen, 2007). In this case, teachers' beliefs and identity (e.g. task concept and self-image) have also been influenced and shaped by their own previous educational experiences, the policy of the school where they work and the development in education and in particular the technology curriculum.

\section{Purpose of the study}

Although the professional identity of teachers can be crucial, there is little knowledge and understanding of this concept of technical VET teachers. Understanding the underlying reasoning behind teachers' teaching strategies at meaningful but bumpy times can reveal the extent to which these strategies meet students' learning needs and their career development for the professional field. To this end we questioned which situations technical VET-teachers experience as bumpy and critical moments and what professional identity (task concept and self-image) underlies their interventions. In accordance with the theoretical models used, we were also interested in two sub-questions. Firstly, can these bumpy moments be categorised according to the petals of the flower model? And if so, what is the distribution amongst the petals? Secondly, how do the bumpy moments relate to the teachers' perceived task concept and selfimage, as reflected in their professional identity? 


\section{RESEARCH METHOD}

To investigate teachers' professional identity an explorative study was carried out among teachers in primary, secondary, and higher vocational education in Technology departments. An in-depth study was carried out by interviewing teachers regarding the bumpy moments they experienced in their class(es). A bumpy moment was defined as 'that moment in which the teacher feels the need to adapt his teaching strategy consciously, to meet specific cognitive or pedagogical goals'. We used the flower model to categorise the teachers' point of view concerning their task, their task concept and self-image. The conversations provided a deep insight into what the teachers thought they must do, which in turn led to a revealing of their professional identity. A mixed method was used for this purpose.

\section{Participants}

Teachers, working at four different levels of technical VET were invited to participate. Their schools were affiliated with the Technical Teacher Training Institute (TTI) where the research group worked. Eleven teachers participated, all teaching Engineering subjects. Two teacher trainers were also involved because they educated technical vocational education teachers. All teachers were men, between 30 and 64 years of age. All but one had more than five years of teaching experience and approximately half of them had a previous career in business. Table 1 shows the distribution of the number of teachers per level of VET, and respective characteristics.

\begin{tabular}{cccccc}
\hline \multirow{2}{*}{$\begin{array}{c}\text { Teacher } \\
\text { code }\end{array}$} & $\begin{array}{c}\text { Type of } \\
\text { education* }\end{array}$ & $\begin{array}{c}\text { Years } \\
\text { of age }\end{array}$ & $\begin{array}{c}\text { Years of } \\
\text { teaching }\end{array}$ & Professional carrier \\
\cline { 6 - 7 } T1 & H-VET TTI & 64 & 32 & Education & Business \\
T2 & H-VET TTI & 53 & 25 & + & \\
T3 & H-VET & 44 & 3 & + & \\
T4 & H-VET & 30 & 7 & + & + \\
T5 & H-VET & 37 & 6 & & + \\
T6 & S-VET & 61 & 35 & + & + \\
T7 & S-VET & 51 & 10 & & + \\
T8 & S-VET & 47 & 15 & + & + \\
T9 & P-VET & 50 & 20 & & + \\
T10 & P-VET & 42 & 15 & & + \\
T11 & P-VET & 25 & 2 & + & + \\
\hline
\end{tabular}

*TTI: Teacher Trainer Institute; VET: Vocational Education in Technology (P: Primary level, S: Secondary level, H: Higher level). M: Mean

Table 1. Characteristics of participants 


\section{Procedure and instruments}

In an introductory session each participant was informed about the aim and design of the study, and various background variables were taken into consideration (age, career history and educational experiences, personal vision on the mission of the school/department). An appointment was made to visit, observe and record a single lesson, for which three criteria applied: a) max. 1 hour; b) including an instruction moment of approx. 15 minutes; c) a group of at least ten students. After the lesson was observed and video-taped, each participant was invited to select five bumpy moments. The definition of a bumpy moment was given, and if necessary, explained more fully. One week after the observation, the respective teachers sent an e-mail with the five time slots selected as bumpy moments, accompanied by a brief argumentation of their choices. This was followed by a semi-structured and in-depth interview covering two topics: clarification of the bumpy moments and the subsequent situation perceived to be at stake by the teacher. This interview was executed by means of schoolvideo-observation (Janssen, 2011; Schildwacht, Bolhuis, \& Van den Akker, 2007). Questions also referred to the task concept and self-image. The interviews were audio-taped and transcribed verbatim.

\section{Analysis}

Firstly, text fragments concerning the bumpy moments were selected from the transcript. All researchers were required to agree on the selections made. Secondly, a scheme was developed to analyse the selected fragments from the bumpy moments. This scheme (see Figure 4) consisted of five aspects:

1. the reason; why this was considered a bumpy moment for the teacher,

2. the friction: the actual heat point of the situation,

3. teacher's approach to dealing with the situation,

4. the intended effect with regard to the learning processes and/or behaviour, and

5. the effect achieved according to the teacher.

Thirdly, to maximise the reliability of transcription analysis. Each researcher first having independently analysed the bumpy moments of two participants who had not been observed and interviewed by themselves. At this stage, they have applied the developed scheme (see Table 2). The analyses were compared and discussed. Fourthly, bumpy moments fragments were summarised to obtain the core of the fragment, which led to a determination of who or what was involved in the bumpy moment and to which 'petal' the bumpy moment could be connected. All researchers exchanged transcripts, so that analyses of two re- 
searchers were available for each transcript. The analyses were compared and discussed. After discussing the differences (approx. 5\%), the inter-coderreliability reached $100 \%$. Based on this method, all bumpy moments could be located in the scheme. Most cells ultimately represented a combination of two elements of the flower-model (see Table 2). Finally, the analysis of the transcripts on professional identity led to a second categorisation scheme on the task perception of the teachers, and dominant I-positions in their professional identity (see Table 3).

\section{FINDINGS}

Most teachers reported at least five bumpy moments. One teacher had difficulties in recalling or recognising bumpy moments. By discussing different time slots with the respective researcher, he finally mentioned one. In summary, a total of fifty-one bumpy moments were reported: TTI teachers noted six bumpy moments, and fifteen by the three teachers teaching any other level of vocational education and training. In order to provide an in-depth picture of the bumpy moments as expressed by the participants, part of an interview is shown in Example of a bumpy moment (T2). During this bumpy moment, the question was how to deal with relevant information concerning examination procedures regarding students who arrive too late. The teacher was annoyed by the students' unmotivated attitude. This caused an emotional friction (internal), which, according to his own explanation, he did not show because of his professional attitude (external). In a dialogue with the researcher he gave thought to this situation and considered how he could involve the students in the study and specifically in his classes. During this bumpy moment, both the attitude of the students and the didactical consequences for the teacher were at stake. Therefore, this bumpy moment was labelled as target group/ didactical method.

\section{Example of a bumpy moment ( $\mathrm{T} 2)$}

At this moment, the teacher temporarily gave lessons to technical business organisations. This concerned different machines for cutting steel (diamond, water, laser techniques) for first-year students Engineering.

- The issue: students arriving late for class: teacher starts his lesson exactly on time. Several students are late, but are still coming into the classroom. The teacher repeatedly informs the latecomers about a number of issues (content) and the (important) information they have missed. He focuses on an instruction on how to apply for an exam next week, and the form they need to fill in. 
- Friction: The teacher has his doubts about the chaotic organisation at the beginning of his lesson; a great deal of repeated information is required because the students enter the classroom at different times. The underlying friction: his irritation regarding the unmotivated attitude of some students.

- Approach to deal with the situation: 'I admit it's not the best way to act, but it has to be done. If I had to wait until the end of class, I'd forget to mention it. Then I won't have the students' email addresses to mail their exam results'.

- The intended effect with regard to the students' learning process: '....when you see me on film I look calm, but if I remember these moments... there's a lot going on in my head. I look really at ease... Maybe it's because I' $m$ an experienced teacher, but inside I think, "Come on! Be on time!" I go to a lot of trouble to prepare my classes, I've got all my stuff with me... Why don't you try your best... and they'll show you this attitude! They come in slowly and unmotivated... lounge in their chairs... open their laptop very slowly... Why can't I motivate them to read a textbook in an enthusiastic way and come to class... Yeah, he'll tell us what's important'.

- 'I just want to motivate my students to think: "Hey, this is fun, I want to know more about this subject!" I want to make them enthusiastic about Technology... This week one of them - he's looking on his cell phone "Hey sir, I have just found something!" and this student had sent me a sample of something we discussed in class. He found an image of a rolling system and how it's forged, something we were talking about earlier "look what I found here!" These are the types of students I like!'

- The 'real' effect achieved (according to the teacher): Chaotic lesson. 'Maybe because I contemplate things too much. But also by those students who come into my class. I have been teaching Technical Business for three years now, but I am aware that we need to change this. Although the exam results aren't bad. My colleague, who used to teach this subject, had even less success than I did. Students are also satisfied... but I think we can do better. And we hope by shortening the time of our lessons - when I see this video tape - that the attention curve of the students can improve. Because I can well imagine - if you're not familiar with this content - if you see me - and as a student you get a flood of information that after half an hour you'll have to think: (sighs) "poooh, what's all this?" and after an hour you'll think "phew... we have to go another hour?" 
And I'll try to... is there a storyline in my class? I'm trying to build a bridge. If that's how you do it... does it work? And when you do it like that... so there's a storyline in it... but if you miss the connection somewhere, you have no idea what's happening - you miss the storyline. That's something l've discovered now...'

Table 2 shows the scheme in which all bumpy moments are classified into one of the (combined) petals of the flower model. Most bumpy moments relate to a combination of two segments. The two lines at the bottom of the table, target group and context, are mentioned separately because, according to the teachers, the respective bumpy experiences relate to a more general behaviour or attitude of the students, apart from classroom situations during the observations. Over half of the bumpy moments $(53 \%)$ occur in the area of content/didactical methods. One third of the bumpy moments (33\%) are related to the target group, and in as many cases teachers are distracted by the students, which they relate to their didactic methods. Bumpy moments that refer to the context were registered only twice. One of them was a situation in the classroom that was right at the heart of the professional identity, and concerned

\begin{tabular}{|c|c|c|c|c|}
\hline \multicolumn{2}{|c|}{$\begin{array}{l}\text { BM-type (flower } \\
\text { model) }\end{array}$} & \multicolumn{2}{|r|}{ Examples of BMs } & Number \\
\hline \multirow[t]{5}{*}{$\begin{array}{l}\text { Pedagogical } \\
\text { /didactical } \\
\text { teaching } \\
\text { methods ... } \\
\text { related to: }\end{array}$} & Content & $\begin{array}{l}\text { - Students c } \\
\text { - Too much } \\
\text { for choice o } \\
\text { - Differenti } \\
\text { questions an } \\
\text { ible) }\end{array}$ & $\begin{array}{l}\text { don't understand (previous taught) content } \\
\text { content for a lesson, which has consequences } \\
\text { f didactical methods } \\
\text { ation and dealing with students (unexpected) } \\
\text { id solutions (making their learning process vis- }\end{array}$ & 27 \\
\hline & \multirow{2}{*}{\multicolumn{2}{|c|}{ Target group }} & - Students are late & \\
\hline & & & $\begin{array}{l}\text { - Distracted students caused by lack of } \\
\text { preparation }\end{array}$ & 7 \\
\hline & \multicolumn{2}{|c|}{ Didactical } & $\begin{array}{l}\text { - Change of groups or didactical methods } \\
\text { - Dealing with questions }\end{array}$ & 5 \\
\hline & \multicolumn{2}{|l|}{ Context } & $\begin{array}{l}\text { - Planning by students for a skills competi- } \\
\text { tion }\end{array}$ & 1 \\
\hline Target group & & (Behaviour) & $\begin{array}{l}\text { - Dealing with less motivated students } \\
\text { - Class rules (e.g. use of smartphone) } \\
\text { - Bold behaviour }\end{array}$ & 10 \\
\hline \multirow{2}{*}{\multicolumn{2}{|c|}{ Context }} & (Language) & $\begin{array}{l}\text { - Student don't understand the emphasis on } \\
\text { how they use language (which is important } \\
\text { for the professional practice) }\end{array}$ & 1 \\
\hline & & & Summarised & 51 \\
\hline
\end{tabular}

Table 2. Bumpy Moments categorised according to the flower model 
the teachers' competencies regarding his craftsmanship. The other situation concerned an adjacent subject, subject language. This is certainly relevant for being able to function well in work and society.

Table 3 shows the distribution of the fifty-one bumpy moments over the educational level (legend on the right) per petal of the flower-model.

\begin{tabular}{lccccccc}
\hline & Targetgroup & $\begin{array}{c}\text { Didact.meths/ } \\
\text { Target group }\end{array}$ & Didact.meths & $\begin{array}{c}\text { Didact.meths/ } \\
\text { Content }\end{array}$ & $\begin{array}{c}\text { Didact.meths/ } \\
\text { Context }\end{array}$ & Context & Total \\
\hline h-vet tti & 1 & 1 & 1 & 3 & - & - & 6 \\
h-vet & 2 & 3 & 3 & 7 & - & - & 15 \\
s-vet & 5 & 2 & 1 & 7 & - & - & 15 \\
p-vet & 2 & 1 & - & 10 & 1 & 1 & 15 \\
\hline total & $\mathbf{1 0}$ & $\mathbf{7}$ & $\mathbf{5}$ & $\mathbf{2 7}$ & $\mathbf{1}$ & $\mathbf{1}$ & $\mathbf{5 1}$ \\
\hline
\end{tabular}

Table 3. Number of bumpy moments per education level to (combined) petals of the flower model

The second question was how do the bumpy moments relate to the teachers' perceived task concept and self-image, as reflected in their professional identity? We discussed the bumpy moments as chosen by the teachers themselves. The teachers' underlying beliefs elicited the dominant I-position as part of their professional identity. The data is summarised in one key sentence in Table 4 .

The results in Table 4 show that instructor T1 and T2, both of which, have a task concept that all content must be dealt with. This means that teachers use didactic methods in which they play a central role. For T1, the I-position as a subject matter expert (focused on content) is dominant in his professional identity, he experiences his role as being primarily responsible for 'information transfer', while according to his conviction the students themselves are responsible for their own learning process. Even when professional misconceptions became clear during his lesson, this teacher failed in identifying bumpy moments. As a result, T1 sees himself as a content expert and less as a students' coach (dominant I-position in his self-image). T2 also believed that all content should be taught (task concept), but in contrast he perceives himself as a teacher being responsible for educational design and didactical methods that should stimulate students' motivation and learning process. Although the design of this lesson is predominantly teacher-centred (current I-position), he preferred to see himself as the student's coach (desired future I-position). 


\begin{tabular}{|c|c|}
\hline $\begin{array}{l}\text { Level of } \\
\text { education }\end{array}$ & Task concept and I-positions (as part of professional identity) \\
\hline \multirow{3}{*}{$\begin{array}{l}\text { 1. Higher } \\
\text { VET - TTI }\end{array}$} & Both teachers beliefs: All content should be taught (teacher centered) \\
\hline & T1. Students are responsible for their learning \\
\hline & $\begin{array}{l}\text { T2. Teacher is responsible and should motivate students by guiding their learning process } \\
\text { actively (eye-opener) }\end{array}$ \\
\hline \multirow{3}{*}{$\begin{array}{l}\text { 2. Higher } \\
\text { VET }\end{array}$} & $\begin{array}{l}\text { T3. Lessons are mainly teacher centered with instruction and individual studying, teacher } \\
\text { wants to make it more interactive to improve students' learning processes. }\end{array}$ \\
\hline & $\begin{array}{l}\text { T4. Teacher uses a traditional repertoire for his lessons, has experiences with alternative } \\
\text { (more activating) lessons, but lacks time and energy to really innovate his lessons }\end{array}$ \\
\hline & $\begin{array}{l}\text { T5. Wants to guide students in working together and enable them to achieve high stand- } \\
\text { ards }\end{array}$ \\
\hline \multirow{3}{*}{$\begin{array}{l}\text { 3. Second- } \\
\text { ary VET }\end{array}$} & T6. Making content-related mistakes is a powerful learning opportunity for students \\
\hline & $\begin{array}{l}\text { T7. Students should understand content, teacher has difficulty with adapting didactical } \\
\text { teaching methods to target group (eg for dyslectic students) }\end{array}$ \\
\hline & $\begin{array}{l}\text { T8. Is committed to his team, but wants to deepen the content of his lessons; BMs are } \\
\text { mostly content related }\end{array}$ \\
\hline \multirow{3}{*}{$\begin{array}{l}\text { 4. Primary } \\
\text { VET }\end{array}$} & $\begin{array}{l}\text { T9. A fixed lesson pattern (instruction by teacher followed by individual working by stu- } \\
\text { dents) provides clarity and structure for the students and provides class overview and in- } \\
\text { sight in students' assumptions in their learning processes }\end{array}$ \\
\hline & $\begin{array}{l}\text { T10. By asking a lot of questions students are stimulated to think for themselves (instead } \\
\text { of passive consuming the lesson) }\end{array}$ \\
\hline & $\begin{array}{l}\text { T11. Belief: the younger the students, the less students can work independently, so the } \\
\text { more explanation and instruction they need from the teacher. }\end{array}$ \\
\hline
\end{tabular}

Table 4. Teachers' professional identity summarised for every single teacher

Participants T3, T4 and T5 who also taught in higher vocational education and training differ somewhat in their task concepts and I-positions. Two of them organised their lessons in a more teacher-centred way, giving instruction and performing exercises with students. However, they wanted to use more interactive strategies (desired I-position) but were not sure how to do that (I as hesitant) and did not have time to change their lessons. Hence by reflecting on their bumpy moments and task concepts in dialogue with the researcher, they became aware of these conflicting I-positions. Teacher T5, on the other hand, was mainly focused on guiding his students to achieve high standards (task concept). It was this teacher who was particularly interested in the learning processes of the students, their prior knowledge and misconceptions, and he was tempted by the question of how far he could evoke and anticipate on these students' (mis)conceptions. In this way he reflected a dominant I-position as a students' coach as well as a subject's expert.

Teachers in secondary VET were most and for all concerned about students' learning processes and expressed dominant I-positions as a students' coach. 
Teacher T6 perceived making content-related mistakes as a powerful learning opportunity for students (task concept). Teacher T7 assumed that all students should understand the subject matter, but lacks didactic teaching methods to deal with diversity in this respect among his students. For example, how to approach dyslectic students. He experienced conflicting I-positions as a subject expert and didactical master. Teacher T8 showed traditional didactical teaching methods because that was agreed upon with his colleagues, although he wanted to teach in an alternative manner in order to enrich and add depth to his lessons. Here two different I-positions ( $I$ as an innovative teacher and $I$ as a colleague) were in conflict.

In primary education and training the students are quite young (12-16 years). These teachers (T9, T10 and T11) formulated a task concept that focuses on the learning processes of the students. However, they differ to some extent in the underlying subjective beliefs in what 'works best' in the type of education: to follow a fixed lesson pattern to provide a clear structure (T9), by asking a lot of questions to stimulate students' autonomous conceptual thinking (T10). The younger the students, the less they can work independently, and consequently more explanation and instruction is needed from the teacher (T11). Hence, this illustrates how teachers' underlying beliefs or task concept as part of their professional identity (what a 'good' teacher should do) result in a variety of teaching behaviour.

\section{CONCLUSION AND DISCUSSION}

Based on previous research in vocational education in the technical domain, this study focused on different types of pedagogical concerns experienced by teachers in technical vocational education in the course of their lessons. In order to gain more insight into how teachers perceive themselves and their task with respect to their students' learning processes, bumpy moments were examined as critical teaching situations in their practice. These bumpy moments represent unexpected situations whereby the teacher feels called upon to act. Our research focused on bumpy moments, seen as critical incidents and meaningful experiences which reveal the professional identity of teachers. Therefore, we questioned what situations do technical VET-teachers experience as bumpy moments, according to the petals of the flower model, and what professional identity (task concept and self-image) underlies their interventions?

\section{Conclusion and discussion}

Firstly, how are these bumpy moments related to the petals of the flower model? Most of the bumpy moments selected by the teachers relate to the con- 
tent of their lesson in relation to the didactic methods used. Misunderstanding by students was often experienced as a critical situation that forced teachers to perform in an alternative way as planned. They felt the need to adapt their teaching strategies to their students' understanding, to attain the lesson's objective. We can therefore cautiously conclude that Technology teachers mainly focused on the cognitive development of the students. Other bumpy moments focused on the target group, i.e. students' behaviour. For example, when teachers failed to understand the student's behaviour or became irritated with less motivated students. In other words, most of the bumpy moments related to the combination of the content and the pedagogical and didactic strategies (axis from top left to bottom right). This indicates that the participating teachers mainly pay attention to topics that coincide with the PCK (Shulman, 1986).

Bumpy situations referring to the context were only registered twice. It does not mean that teachers do not make a connection in their lessons with the work processes of the work field. We can only conclude that teachers do not experience these context related aspects as bumpy moments. It may not be seen as a problem for them. From a business perspective, considering half of these teachers have a business background, they could probably relate heartfelt stories from the field. Being able to teach based on their past professional expertise, they probably experienced little discomfort and as such did not experience any bumpy moments in that field. It could also mean teachers do not focus on guiding students towards a future in Technology subjects (axis from left below to upper right side). This is in line with earlier research that showed that teachers and educators in the technical domain predominantly act in education as content experts (Klatter \& Stroetinga, 2011).

It could be argued that it is mainly lateral entry teachers from the business world, who find it difficult to get a grip on the learning process of their students and to make adjustments to their pedagogical/didactical methods. For this reason, they mainly focus on the content of the subject matter, rather than on students' learning processes in order to equip them for a skilled profession (Janssen, 2012; Klatter \& Vloet, 2013).

Secondly, how do the bumpy moments relate to the teachers' perceived task concept and self-image, as reflected in their professional identity? The analyses of the interviews showed different I-positions, varying from tutors who mainly see their role as providing the content (subject matter expert), to teachers who are more concerned with the students and their learning process (student coach). I-positions related to the context (craftsman or innovator) were not noticed as bumpy moments or were taken for granted. I-positions as a 'subject matter expert' and as a 'didacticus' in educational practice may collide. As

http://quadernsdepsicologia.cat 
teachers' identity predominantly referred to content and didactical issues, their task-concept seems to be focused on students' cognitive development. However, some teachers were more focused on the target-group, emerging as a dominant I-position as 'students' coach'. Teachers' perspective on the professional orientation and introduction of their students to the field of work however, remained underexposed.

In dialogue with the interviewer, some teachers realised they were mainly focused on information transfer, while they wanted their students to become more 'active learners' (Balaji \& Lion, 2016). These bumpy moments revealed the difference in the actual execution of the task and the I-position along which they wanted to shape their education. They do not seem to be sure if their didactical and pedagogical repertoire is suitable for their students' understanding of the content. They were also aware of the numerous times that students struggle with learning, with understanding or being able to begin performing their tasks, but the teachers were not able to support them in an adequate fashion.

The focus on the two well-known segments of the flower model, which correspond to the PCK, confirms that even teachers in vocational education pay predominant attention to the cognitive development of their students (axis: from top left to bottom right). Little attention is payed to students' wishes and ambitions for their professional future. Alternative labour market contexts should be more explicitly incorporated in order to prompt students to explore their underlying values and beliefs, in preparation for their future employment prospects in an ever-changing world. In order to achieve powerful vocational education, teachers will have to focus more on the segment' context and target group. Initially, this will require a task concept that meets this mission, and an associated I-position as a (career) coach for students.

\section{Limitations of this study}

There are a number of limitations of this study. As the study aims to explore the petals and identity of technical teachers, a small group of teachers was interviewed to be able to analyse the interviews in an in-depth narrative and dialogical way. Consequently, a small number of VET-teachers participated which makes it impossible to generalise our conclusions to VET-teachers in general and to separate our results for different educational levels. It is imperative that we remain cautious in drawing our conclusions

A second aspect of the study that may be up for criticism is the main focus on teachers' perspective. It would be interesting to include the students' perspective on this point: if and what they noticed of their teacher's bumpy moments 
and what the real effect of the teachers' actions were on their learning process or behaviour. For instance: whether misconceptions were clarified after the teacher changed his educational strategy. These questions could be leading for future research.

A third limitation of our study is that the teacher's professional identity and dialogical self in relation to their bumpy moments were not explicitly discussed with the interviewers, but were analysed afterwards by them. It would be more in line with the Dialogical Self Theory when there would be a real dialogue with the participating teachers about their professional identity. We argue that this external dialogue with a researcher (or coach or colleague), could improve teachers' agency and ownership in professionalisation and in teacher education.

\section{Professionalisation}

Bumpy moments can be perceived as critical incidents that might cause teachers to (re)think their professional identity. They can also be recognised as situations that, from the teacher's perspective, legitimately permits a different or alternative teaching strategy (Romano, 2006). Teachers do feel the urge to change their didactic repertoire, which requires a professionalisation that focuses on the learning processes of the students. Findings based on the interview analysis provide starting points for improvements for technical teacher education. These refer to an increasing attention to the professional context, which the individual students ask for, but above all a conscious application of didactic methods.

A poor understanding of the students' actual learning processes can lead to a mismatch between teachers' educational strategies and the processes students are required to carry out. This refers to a professionalisation in the field of formulating learning objectives and to a more intensive alignment, with students' cognitive (and metacognitive) learning processes, which must be performed to ultimately understand the subject at stake. Improving teachers' indepth understanding of students' learning processes, on the one hand, and their pedagogical/didactical strategies, on the other, can contribute to more appropriate choices of learning activities students need to carry out in order to acquire the specific competences. Furthermore, it may be cautiously concluded that the bumpy moments related to didactical issues, skills and knowledge, are based on a lack of awareness of the constructive alignment, a well-known indicator of educational quality (Biggs \& Tang, 1990).

Professionalisation by means of school-video-observation (Janssen, 2011; Schildwacht et al., 2007) can be a powerful way for raising awareness of 
teachers' educational practice, how they react to critical incidents, and to elicit underlying beliefs, motives and fundamental I-positions. Nearly all participants in our study experienced this method as an eye-opener for visualising their pedagogical actions, and way of working on expanding their pedagogical and didactical repertoire for gaining their learning objectives. In this way, school-video-observation can serve as a means of empowering teachers in the exercise of their vulnerable profession (Kelchtermans, 2009).

The Dialogical Self Theory of Hermans and colleagues can be supportive in this process. The conceptual framework of professional identity presented in this study was focused on the representation of what present I-positions were involved. In future teacher training and research, a dialogue with a teacher's coach in follow-up discussions could be used more explicitly. Two epistemological conceptions of identity, which do not always seem to be compatible, were involved in our theoretical framework. A cognitive vision, focusing on concepts such as self-image, in which identity is formed by comparatively stable representations of the person himself, and another, more dialogical vision, as advocated by Akkerman and Meijer (2011). Both were integrated in our study.

A teacher, educator or coach can stimulate teachers' reflection as an internal dialogue on their different I-positions (actual as desired ones) and create a meta position to become aware of all (conflicting) I-positions at stake, and create a way to develop themselves professionally (Hermans \& Hermans-Konopka, 2010, p. 191). In line with Akkerman and Meijer (2011, p. 315) teachers' identity can not only be defined, but also be used as an empowering instrument as "an on-going process of negotiating and inter-relating multiple I-positions in such a way that a more or less coherent and consistent sense of self is maintained throughout various participations and self-investments in one's (working) life." This may improve teachers' awareness that education is designed based on their underlying beliefs and professional identity. Knowledge and recognition of the four segments of the flower model in relation to different Ipositions can help to design a powerful learning environment. Working along the segments of the flower-model may contribute improving the consciousness of the power of adequate pedagogical and didactical choices.

\section{Future research}

Future research within technical VET could focus more on the implicit Ipositions and look for ways in which the professional identity of teachers moves in line with the needs of students and the future requirements of the technical field for which VET educates. Research on how the context can be more integrated in training students for the technical domain is needed. Vigorous tech- 
nical VET requires education that pays attention to the students' interest, their prior knowledge of the labour market, and considers the students' learning strategies. The nature of the bumpy moments in this study illustrates a lack of alignment between teachers' professional identities and the broad educational goals of VET, training students to become competent and professional professionals for lifelong development. Discussing the professional identity of technical VET teachers can then be a first step towards becoming aware of this gap, and working on a broader task concept based on a profound coherent identity.

\section{REFERENCES}

Akkerman, Sanne \& Meijer, Paulien (2011). A dialogical approach to conceptualizing teacher identity. Teaching and Teacher Education, 27(2), 308-319.

https://doi.org/10.1016/j.tate.2010.08.013

Association of Universities of Applied Sciences (2012). Kennisbasis Docent Technische Beroepen (bachelor). [Knowledge Base Technical Professional Teacher.] The Hague: Editors Technical teacher training centres.

Balaji, Uma \& Lyon, Douglas A. (2016). Active learning approach for enhanced student learning in electromagnetic compatibility course. Proceedings of the ASEE northeast section conference, April 2016.

Beijaard, Douwe; Meijer, Paulien \& Verloop, Nico (2004). Reconsidering Research on Teachers' Professional Identity. Teacher and Teacher Education, 20, 107-128. https://doi.org/10.1016/j.tate.2003.07.001

Biggs, John \& Tang, Catherine (2011). Teaching for Quality at University. What the student does (4th edition). New York: McGraw Hill/ SRHE and UOP.

Clandinin, Jean \& Connelly, Michael F. (2000). Narrative inquiry. Experience and Story in Qualitative Research. San Francisco, CA: Jossey-Bass.

Coldron, John, \& Smith, Robin (1999). Active location in teachers' construction of their professional identities. Journal of curriculum studies, 31(6), 711-726. https://doi.org/10.1080/002202799182954

De Bruijn, Elly \& Kleef, Anja, van (2006). Van idee naar interactie: docenten en deelnemers geven vorm aan competentiegericht leren en opleiden. [From idea to interaction: teachers and participants design competence based learning and educating]. Hertogenbosch: Cinop.

De Bruijn, Elly \& Leeman, Yvonne (2011). Authentic and self-directed learning in vocational education: Challenges to vocational educators. Teaching and Teacher Education, 27(4), 694-702. https://doi.org/10.1016/j.tate.2010.11.007

De Putter-Smits, Lesley (2012). Science teachers designing context-based curriculum materials: developing context-based teaching competence. Unpublished dissertation, Eindhoven: Eindhoven University of Technology.

Dewey, John (1922/2002). Human nature and conduct, New York: Prometheus books. 
Dowling, Maura (2007). From Husserl to van Manen. A review of different phenomenological approaches. International journal of nursing studies, 44(1), 131-142. https://doi.org/10.1016/j.ijnurstu.2005.11.026

Feiman-Nemser, Sharon. \& Floden, Robert. E. (1986). The cultures of teaching. In: Wittrock, Merlin C. (Ed). Handbook of research on teaching (pp. 505-526). NewYork: Macmillan.

Fouarge, Didier; Bakens, Jessie; Bijlsma, Ineke; Dijksman, Sander; Peeters, Tim; Poulissen, Davey; Veth, Joost; Künn, Annemarie \& Montizaan, Raymond (2017). De arbeidsmarkt naar opleiding en beroep tot 2022. [Training and occupation for the labour market - till 2022.] Researchcentrum voor Onderwijs en Arbeidsmarkt, Faculteit der Economische Wetenschappen. Maastricht: ROA Reports, Nr. 010. https://doi.org/10.26481/umarep.2017010

Glaudé, Marjan; Verbeek, Fred; Van den Berg, José \& De Bruijn, Elly (2011). Pedagogisch-didactisch handelen van docenten in het middelbaar beroepsonderwijs. Literatuurstudie. [Pedagogical-didactical action by secondary vocational education teachers. Literature study.] s-Hertogenbosch/Utrecht: Expertisecentrum Beroepsonderwijs.

Grootendorst, Anniemiek (2019). Professionele Identiteit ontwikkelen gedurende de hbo-opleiding. Een handreiking. Hogeschool Rotterdam. [Developing a professional identity during higher professional education. A helping hand. Rotterdam University of Applied Sciences.] Rotterdam: Hogeschool Rotterdam.

Hattie, John (2012). Visible learning for teachers: Maximizing impact on learning. New York/London: Routledge.

Hermans, Hubert J.M. \& Kempen, Harry J.G. (1993). The dialogical self. Meaning as movement. San Diego: Academic Press.

Hermans, Hubert J.M. \& Hermans-Konopka, Agnieszka (2010). Dialogical Self Theory. Positioning and Counter-Positioning in a Globalizing Society. New York: Cambridge University Press.

Janssen, Hans (2011). Verbondenheid in beeld. 10 jaar School Video Interactie Begeleiding [Connectedness in view. 10 years of School Video Interaction Guidance]. Amersfoort: Uitgeverij Agiel.

Janssen, Nico (2012). Didactische werkvormen in het technisch beroepsonderwijs, bij docenten. Fontys Hogescholen, Eindhoven. [Teachers' pedagogical methods in Vocational Education Technology in Fontys University of Applied Sciences] Unpublished Master thesis. Universiteit Utrecht.

Kelchtermans, Geert (1994). De professionele ontwikkeling van leerkrachten vanuit het biografisch perspectief. [Teachers' professional development from the biographical perspective]. (Doctoral Thesis) Leuven: University Press.

Kelchtermans, Geert (2009). Who I am in how I teach is the message: selfunderstanding, vulnerability and reflection. Teachers and teaching: Theory and Practice, 15(2), 257-272. https://doi.org/10.1080/13540600902875332

Kerby, Anthony P. (1991). Narrative and the self. Indiana: Indiana University Press.

Klatter, Ellen B. (2015). Professionele identiteit in perspectief. Intensieve relaties voor ijzersterk beroepsonderwijs. [Professional identity in perspective. Intensive 
relations for strong vocational education]. Rotterdam: Hogeschool Rotterdam Uitgeverij.

Klatter, Ellen B. \& Stroetinga, Erik-Jan (2011). PCK in the context of technology. Poster presented at EAPRIL conference. November, Nijmegen.

Klatter, Ellen B. \& Vloet, Kara (2013). Exploring Teachers' Pedagogical Content Knowledge (PCK) and Professional Identity (TPI) in the context of Applied Technology in Higher Education. Paper presentation EAPRIL, Biel, Switzerland.

Korthagen, Fred \& Vasalos, Angelo (2005). Levels in reflection: Core reflection as a means to enhance professional development. Teachers and Teaching: Theory and Practice, 11(1), 47-71. https://doi.org/10.1080/1354060042000337093

Kuijpers, Marinka (2015). Verander SLC. Maak het nuttig, maak het persoonlijk!. Advies voor de ontwikkeling van Studieloopbaancoaching binnen Hogeschool Rotterdam. [Change SLC. Make it useful, make it personal. Advice for the development of Studio Career Coaching within Rotterdam University of Applied Sciences] (Intern rapport). Rotterdam: Hogeschool Rotterdam.

Kunneman, Harry (2010). Ethical Complexity. In: Paul Cilliers \& Rika Preiser (Eds.), Complexity, Difference and Identity. Issues in Business Ethics 26 (pp.131-164). Dordrecht: Springer. https://doi.org/10.1007/978-90-481-9187-1_8

Park, Soonhye \& Oliver, Steve J. (2008). Revisiting the conceptualisation of Pedagogical Content Knowledge (PCK): PCK as a conceptual tool to understand teachers as professionals. Research in Science Education, 38, 261-284. https://doi.org/10.1007/s11165-007-9049-6

Pillen, Marieke (2013). Professional identity tensions of beginning teachers. Unpublished Doctoral thesis, Eindhoven: Eindhoven University of Technology.

Pols, Wouter (2011). Leraren en hun opleiders. Een pleidooi voor de pedagogische professionaliteit'. [Teachers and their trainers. A plea for pedagogical professionalism']. Tijdschrift voor Lerarenopleiders, 32(1), 30-36.

Romano, Molly (2006). "Bumpy moments" in teaching: Reflections from practicing teachers. Teaching and Teacher Education, 22, 973-985.

https://doi.org/10.1016/j.tate.2006.04.019

SBB. (2019). Trendrapport zakelijke dienstverlening en veiligheid. Retrieved from https://trendrapport.s-bb.nl/zdv/technologische-innovaties/

Schildwacht, Rita; Bolhuis, Sanneke \& Van den Akker, Jan (2007). Stimulating teachers' professional development using video feedback with reciprocal peer coaching. In: Benő Csapó \& Csaba Csíkos (Eds.), Developing potentials for learning: abstracts (pp. 403-403). Earli Conference, Budapest.

Schneider, Rebecca M. \& Plasman, Kellie (2011). Science teacher learning progressions: A review of science teachers' pedagogical content knowledge development. Review of Educational Research, 81(4), 530-565. https://doi.org/10.3102/0034654311423382

Shulman, Lee S. (1986). Those who understand: Knowledge growth in teaching. Educational Researcher, 15, 4-14. https://doi.org/10.3102/0013189X015002004

Stuckey, Marc; Hofstein, Avi.; Mamlok-Naaman, Rachel \& Eilks, Ingo. (2013). The meaning of 'relevance' in science education and its implications for the science cur-

http://quadernsdepsicologia.cat 
riculum. Studies in Science Education, 49(1), 1-34.

https: / / doi.org/10.1080/03057267.2013.802463

Techniekpact 2020 (2016). Nationaal techniekpact 2020. Inzet 2016-2020. [National Technology pact 2020. Effort 2016-2020] Retrieved from https: / / www.techniekpact.nl/ doelen/doel-6

Teune, Peter \& Janssen, Sandra (2015). Subject Matter Learning. Paper presented at the International Conference Ingenieur-Pädagogische Wissenschaftgesellschaft, November, Fontys University of Applied Sciences, Eindhoven.

Van Driel, Jan \& Verloop, Nico (2004). 'De PCK van scheikundedocenten-in-opleiding over het gebruik van deeltjesmodellen. [The Pedagogical Content Knowledge (PCK) of chemistry teachers in training on the use of particle models.] Pedagogische Studiën, 81, 273-289.

Van Kan, Carlos; Zitter, Ilya; Brouwer, Patricia \& Van Wijk, Barbara (2014). Onderwijspedagogische visies van mbo-docenten; wat dient het belang van studenten? [Educational pedagogical visions of teachers in secondary Vocational Education; what serves the interest of students?] 's Hertogenbosch: Centre of Expertise for Vocational Education.

Van Manen, Max (2007). Phenomology of practice. Phenomology \& Practice, 1(1), 11 30. https://doi.org/10.29173/pandpr19803

Virtanen, Anne \& Tynjälä, Päivi (2019). Factors explaining the learning of generic skills: a study of university students' experiences. Teaching in Higher Education, 24(7), 880-894. https://doi.org/10.1080/13562517.2018.1515195

Volkmann, Mark J. \& Anderson, Maria A. (1998). Creating professional identity: Dilemmas and metaphors of a first-year chemistry teacher. Science Education, 82(3), 293-

310. https: / / doi.org/10.1002/(SICI)1089-237X(199806)82:3<293::AID-SCE1>30.CO;2-7

Vloet, Kara (2015). Professionele identiteitsontwikkeling van leraren als dialogisch proces. Een narratieve studie in een masteropleiding in special onderwijszorg en loopbaanbegeleiding van leerlingen. [Teachers' professional identity development as a dialogical process. A narrative study in a master's programme in special educational care and career guidance of students.] Unpublished Doctoral Thesis, Utrecht: University of Humanities.

Vloet, Kara; Jacobs, Gaby; \& Veugelers, Wiel (2013). Dialogical learning in teachers' professional identities. In: M. César \& B. Ligorio (Eds.). Interplays between dialogical learning and dialogical self. (pp. 419-457). New York: Information Age. 


\section{KARA VLOET}

PhD Social Sciences, lecturer Fontys University of Applied Sciences, Eindhoven. c.vloet@fontys.nl

\section{ELLEN KLATTER}

PhD Social Sciences, Associate Professor Rotterdam University of Applied Sciences, Rotterdam.

e.b.klatter@hr.nl

\section{SANDRA JANSSEN}

PhD Social Sciences, lecturer Fontys University of Applied Sciences, Eindhoven. sandra.janssen@fontys.nl

\section{GIEL KESSELS}

Ma in Education, teacher at Summa College. ghm.kessels@summacollege.nl

\section{FORMATO DE CITACIÓN}

Vloet, Kara; Klatter, Ellen; Janssen, Sandra \& Kessels, Giel (2020). Bumpy moments considered as critical incidents in dialogue. Professional Identity of technical VETteachers. Quaderns de Psicologia, 22(2), e1573. https://doi.org/10.5565/rev/qpsicologia.1573

\section{HISTORIA EDITORIAL}

Recibido: 20-09-2019

$1^{a}$ revisión: 23-03-2020

$2^{\mathrm{a}}$ revisión: $15-07-2020$

Aceptado: 22-07-2020

Publicado: 31-08-2020 